\title{
手術ロボティックシステム開発フロジェクト Surgical Robotic System Project
}

佐久間一郎 ${ }^{\mathrm{a}}$, 小林英津子 ${ }^{\mathrm{a}}$, 辻 隆之 ${ }^{\mathrm{a}}$, 陳 献 ${ }^{\mathrm{a}}$, 久田俊明 ${ }^{\mathrm{a}}$, 増谷佳孝 ${ }^{\mathrm{d}}$, 木村文彦 ${ }^{\mathrm{c}}$, 佐々木 ${ }^{\mathrm{a}} \mathrm{i}^{\mathrm{a}}{ }^{\mathrm{a}}$, 板生 清 ${ }^{\mathrm{a}}$, 岡田昌史 ${ }^{\mathrm{b}}$, 中村仁彦 ${ }^{\mathrm{b}}$, 波多伸彦 ${ }^{\mathrm{b}}$, 土肥健純 ${ }^{\mathrm{b}}$

a 東京大学大学院 新領域創成科学研究科

b 東京大学大学院 情報理工学系研究科

c 東京大学大学院 工学系研究科

d 東京大学医学部放射線科

Ichiro Sakuma ${ }^{\mathrm{a}}$, Etsuko Kobayashi ${ }^{\mathrm{a}}$, Takayuki Tsuji ${ }^{\mathrm{a}}$, Xian Chen ${ }^{\mathrm{a}}$, Toshiaki Hisada ${ }^{\mathrm{a}}$, Yoshitaka Masutani ${ }^{\mathrm{d}}$, Fumihiko Kimura ${ }^{\mathrm{c}}$, Ken Sasaki ${ }^{\mathrm{a}}$, Kiyoshi Itao ${ }^{\mathrm{a}}$, Masashi Okada ${ }^{\mathrm{b}}$, Yoshihiko Nakamura ${ }^{\mathrm{b}}$, Nobuhiko Hata, Takeyoshi Dohib

a Graduate School of Frontier Science, the University of Tokyo

${ }^{\mathrm{b}}$ Graduate School of Information Science, the University of Tokyo

' Graduate School of Engineering, the University of Tokyo

${ }^{d}$ Department of Radiology, Faculty of Medicine, the University of Tokyo

\begin{abstract}
In this paper, we described the overview of JSPS research for the future program, Development of Robotic System for surgery and introduced some researches in this project. The aims of this project are 1) development of the master-slave manipulator system for minimally invasive liver surgery including deformable biomechanical liver model development and 2) development of the laser guidance system, the needle insertion robot and related technologies for orthopedic surgery. We made this study collaborating with Kyushu University and Osaka University. We also aim for practical use of surgical robot through promotion of business-academia collaboration.
\end{abstract}

Key words Medical robot, Minimally invasive surgery, Deformable model of the liver.

\section{1.はじめに}

本プロジェクトにおいては，骨格系を対象とする 手術支援と, 軟性臓器を対象とする手術支援のため のロボットシステムを研究対象として,

1）手術ロボティクスの制御・ナビゲーションにお いて重要となる, 主に肝臟を対象とした軟性臓

* 東京大学大学院新領域創成科学研究科環境学専攻

T 113-8656 文京区本郷 7-3-1

Tel. 03-5841-7481 / Fax. 03-841-6481

\section{器の変形解析の研究}

2）低侵襲腹部外科手術ロボット開発

3）低侵襲整形外科手術用ロボティクス の研究を進めている，1），2）においては，九州大学 大学院橋爪班，3）に関しては大阪大学大学院菅野班 との密接な連携により研究を実施している.

肝臓を詨象とした軟性臓器の変形解析の研究にお いては, (1)力学的に厳密な有限要素法を用いた変形 解析, (2)近似的解法による肝臓変形の実時間変形シ ミュレーション，(3)モデルと術中画像を組み合わせ るためのレジストレーション法の検討を行なつてい る. 

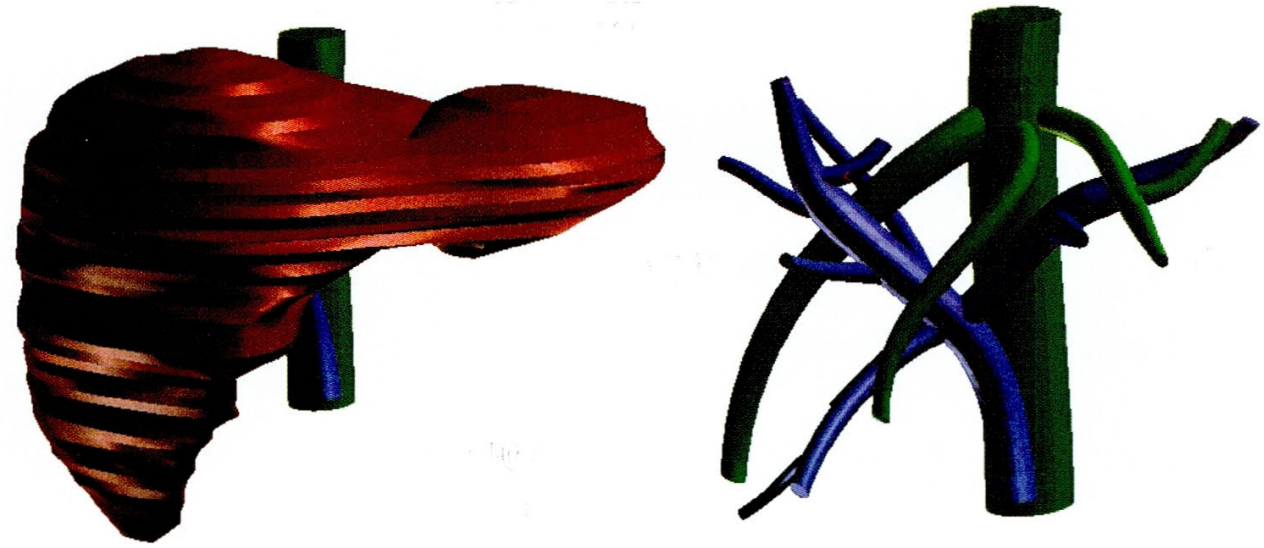

Fig. 1 Prototype of the finite element model of liver.

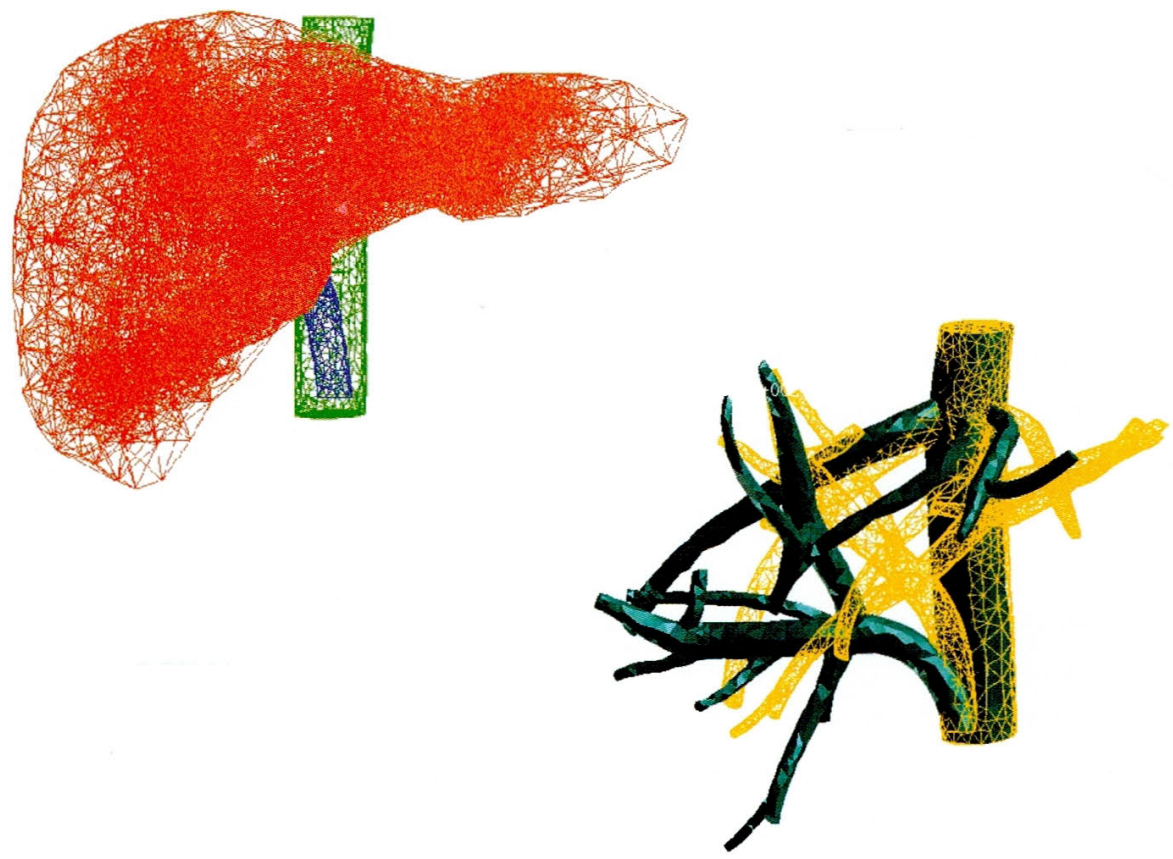

Fig. 2 Finite element mesh made from liver model.

低侵襲腹部外科手術ロボットシステムにおいては， 高機能内視鏡下手術用マスタースレーブシステムの 開発を進めている。腹壁上に 3 本の能動鉗子を配置 できる程度の小型のスレーブマニピュレータシステ ムの開発を進めている。また腹腔内を観察する内視 鏡マニピュレータに関しては, 安全性を考慮した 5 節リンク方式の腹腔鏡マニピュレー夕を本プロジェ クトで実用化した。鉗子機能に関しても把持・切除 といった基本的な機能に加え，レーザ凝固・切開機 能，電気义ス機能を付加した能動鉗子の開発を進め ている. マスタースレーブマニピュレータを中心と
する各種医用画像システム・ナビゲーションシステム などの総合的なシステム統合の手段として CORBA を用いてシステムを統合し，既存のハードウェアや ソフトウェアの変更を最小限にとどめ, 任された夕 スクに適した環境での開発を可能とすることを目標 としている.

整形外科手術支援ロボットシステムに関しては大 阪大学菅野班と連携し，椎体骨穿刺ロボットの開発 を実施するとともに，低侵襲での骨切りを実現する ための骨切ロボットの開発を行なうとともに，精密 な骨切り手法に関し検討している. 


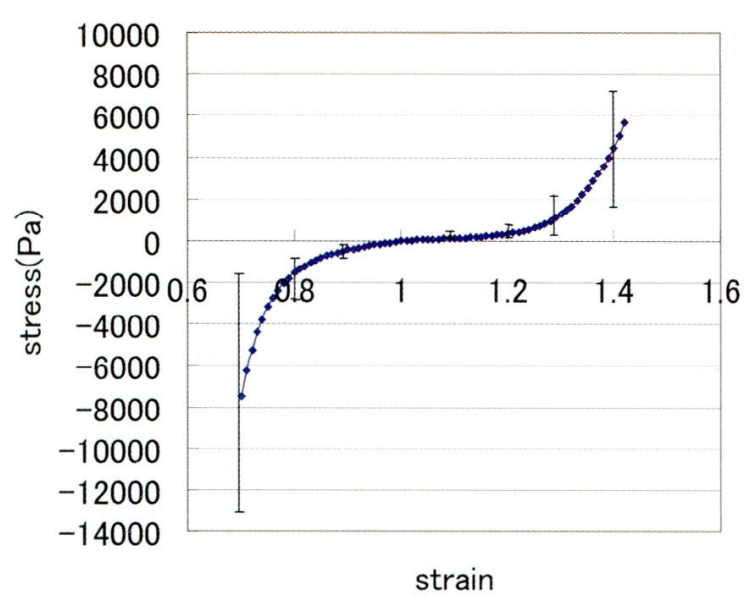

Fig. 3 Stress-strain Curves of compression and elongation test $(n=15)$. Error bar indicates standard deviation.
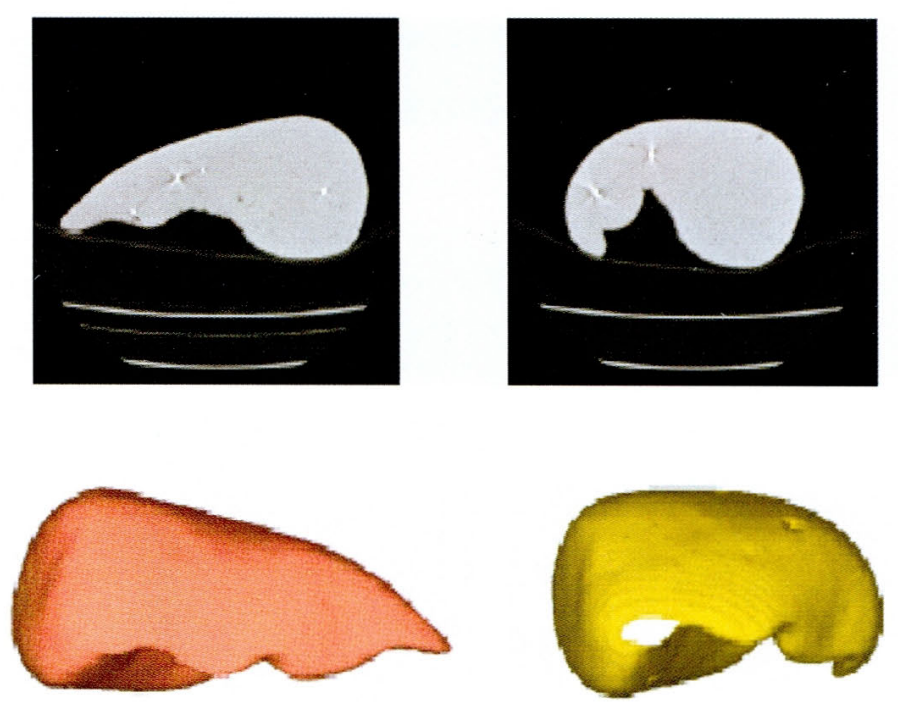

Fig. 4 Deformable silicon phantom. Left: model before deformation, right: model after deformation, up: CT image, down: 3D reconstructed model.

Laparoscope with optical zoom
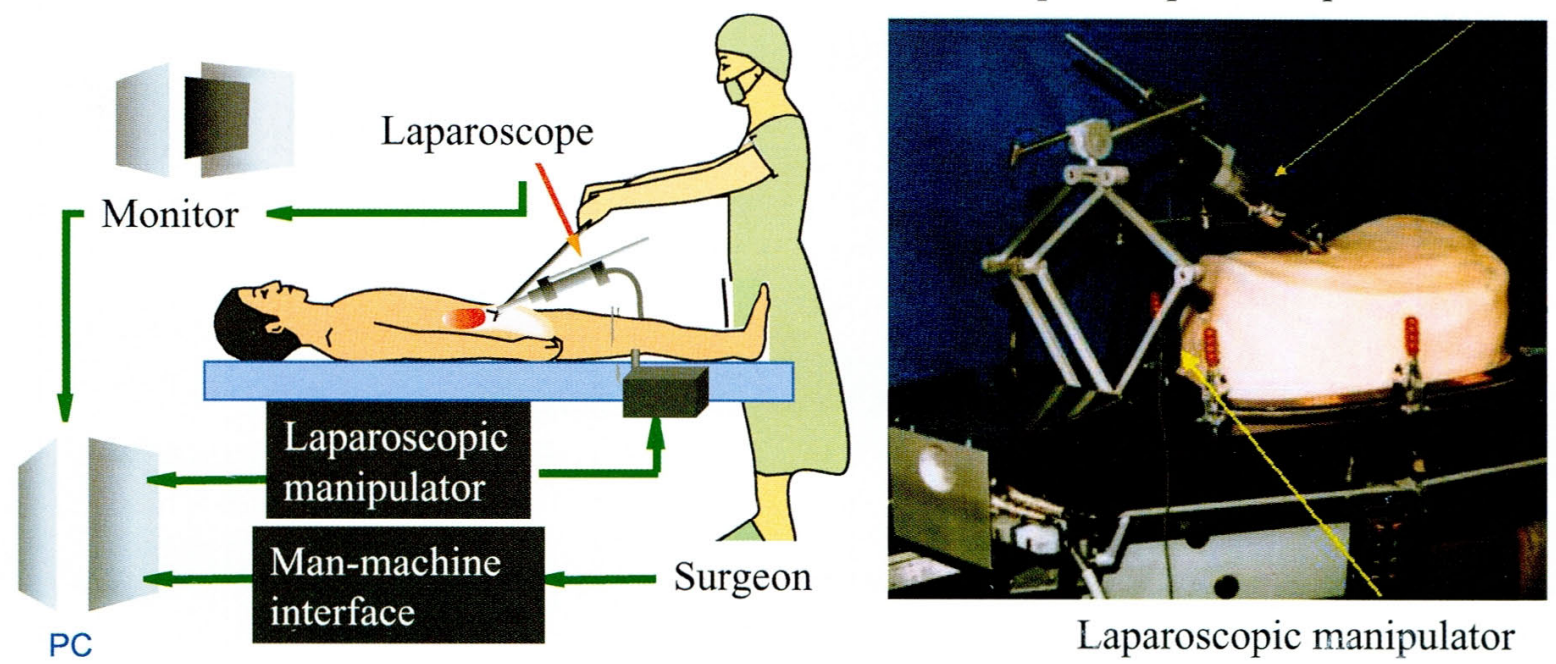

Laparoscopic manipulator

Fig. 5 System configuration of the laparo-navigator system.

Ultrasonic motors

Friction wheel

Fig. 7 Mechanism of compact forceps manipulator using a friction wheel.
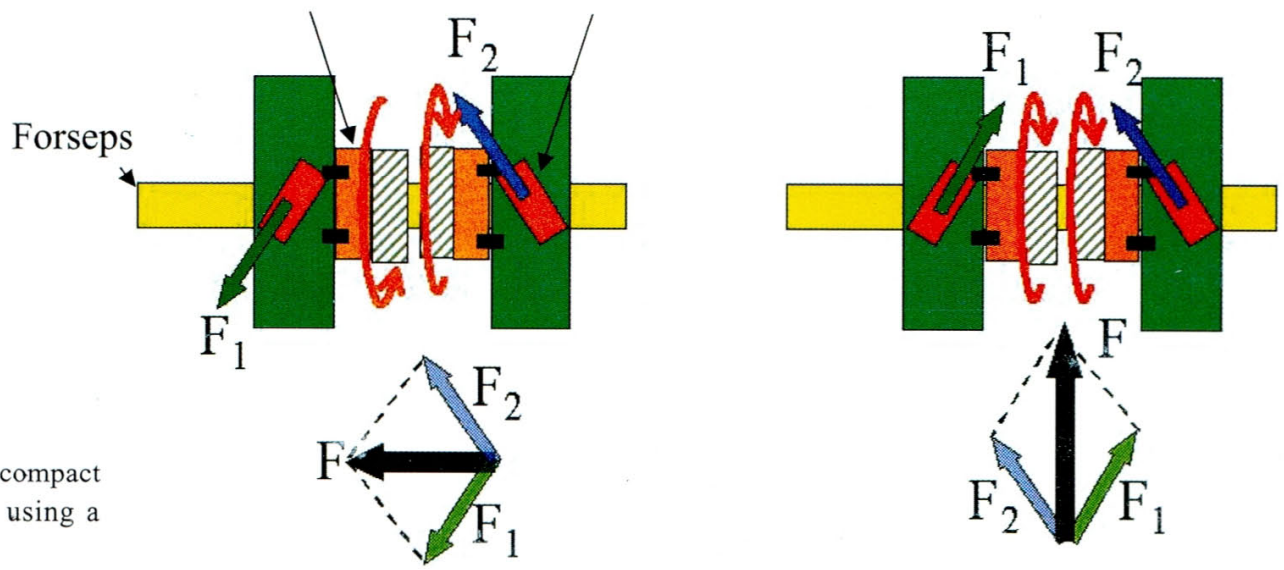
以下にこれらの研究の概要を紹介する.

\section{2. 軟性臓器のモデリング}

\section{（1）臓器変形の非線形有限要素解析}

肝蔵の術中の力学的応答には血圧を有する血管の 剛性が影響を及ぼすと考えられること，また主要な 血管は患部特定の目安となり手術計画の基礎を与え ることから，本研究では肝実質部に加えて主要な血 管もモデル化することを研究の方針としている。そ こで試解析用に，断層画像・参考文献などから凡そ のモデリングを行ない，次にこれをべースに九州大 学橋爪班の協力を得て血管の走行ならびに肝臓形状 が適切なものになるよう修正を施し，最終的な有限 要素モデルのプロトタイプを Fig. 1 に示すように完 成した ${ }^{1)}$.

解析は total lagrange 法を応用しての幾何学非線形 (geometrical non-linear) 解析による。また材料非線 形性（material non-linearity）としては，歪みととも に硬化が進むいわゆるJ字型の非線形弾性構成則を 仮定した解析例を Fig. 2 に示す. 切除ラインを指定 し割面が進展する場合のシミュレーションも行なう ことが可能である.

\section{（2）肝臓力学物性の計測}

以上の有限要素解析するためには肝臓の機械的特 性の計測が必要となる。本研究ではブタ肝臓から取 り出した円柱状切片を外科用接着剂でプレートに固 定することで，同一試験片に対して引張・圧縮試験 を行なうことを可能とし，機械的な特性試験を行な っている．試験により得られた公称応力ーひずみ関 係の一例を Fig. 3 に示す. 今後実験結果をもとに, 解析に適用可能な構成則を求めることを進めている.

\section{（3）実時間シミュレーションシステム}

前述の非線形有限要素解析は現在のところ実時間 で手術ナビゲーションに応用するためには計算コス トが大きいため困難である。本研究では，力学的 な厳密性は有していないが, ある程度臓器変形を再 現し，手術ナビゲーション等に応用可能な高速な臓 器変形のシミュレーション手法を開発している。変 形をいくつかの基本パターンにより合成する手法を 用いることとし，本年度は変形の基本パターンは 形状個々の接学解析に拠らず, 経験的に知られて いる低周波のをードを使用することにした，そし て, 形状の変形の際には，自由形状変形（Free Form Deformation）としてよく知られている，制御点を 用いる手法を用いた。すなわち，制御点群の操作を モードに従って行なうことにより, 形状を変形させ

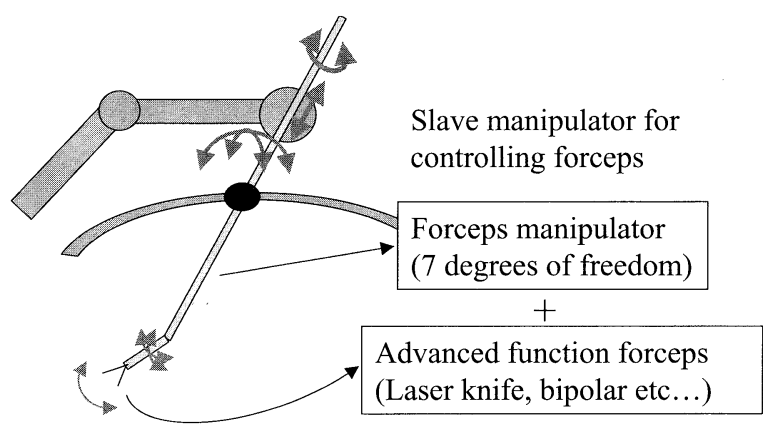

Fig. 6 Frame format of the slave manipulator.

るものである ${ }^{2)}$. 本手法をモード駆動型自由形状変 形 (Modally-driven Free Form Deformation) と呼んで いる. Fig. 4 に変形シミュレーションの一例を示す. 鉛球をマーカーとして埋め込んだシリコンゴムファ ントムに, 各種の変形を与えて, CT 撮影を行ない, その結果を使用して，可変形レジストレーションの 実験を行なった。ファントムの表面形状の情報のみ によるレジストレーションでは，ファントム内部の 鉛球マーカの位置づれも含めた平均残留誤差が 10 $\mathrm{mm}$ 程度となったが，表面形状の情報に加えて，内 部の基準点を使用した場合は，レジストレーション 誤差が $7 \mathrm{~mm}$ 程度に抑えられることが示された。

\section{3. 低侵襲腹部外科手術ロボット開発}

\section{（1）内視鏡マニピュレータの実用化}

腹腔鏡下手術の問題点としては，腹腔鏡を保持し ているカメラ助手と術者との意思疎通がうまくいか ず，術者の望む画面を素早く提示できないこと，ま た手ぶれが生じ，画面が安定しないという点があ り，円滑な手術の妨げとなっている。そこで，われ われはこれを工学的に解決すべく, 腹腔鏡を保持し, 術者の望む方向へ駆動するマニピュレータシステム （腹腔鏡ナビゲータ）を開発し，臨床応用に適用する とともに実用化を行なった ${ }^{3)}$

本マニピュレータのシステム構成を Fig. 5 に示す. システムは腹腔鏡マニピュレータ, マン・マシンイ ンタフェースから構成される．腹腔鏡マニピュレー タは，5節リンク機構と光学式ズームによる機構を 採用し，腹腔鏡の挿入孔付近で球面ジョイントを用 いて腹腔鏡を固定し，離れた点で二次元平面上の位 置決めを行なう。この二次元平面上の位置決めに 5 節リンク機構を採用した。また，画面の拡大縮小に は，機械的な並進を行なわず，光学式ズームを用い た，本機構により，下記の手術室での使用において 
重要な使用を満たす。

機構的安全性 : 5 節リンク機構と光学式ズームを 用いることにより，駆動範囲を機械的に拘束した。 よって，䛊操作時にも予想外の動きを行なわず，前 後動による藏器との干渉の可能性を低減した. また, モータやエンコーダ等の電子部品をすべて下部に設 置し，上部はシンプルなリンク部のみで構成される ため，取りはずして滅菌可能とした。 さらに 5 節リ ンク上部にパッシブアームを取付けることで，マニ ピュレータを術野から離れた位置に設置可能とし, マニピュレータが術者の作業の妨げとならないよう に設計した。

マニピュレータの駆動範囲は，左右方向 $50^{\circ}$ 上下方 向 $30^{\circ}$, ズーム比は最小から最大の比が 6 倍である. また, マン・マシンインタフェースとして, 鉗子取 付型の手元スイッチを用いた.

5 節リンク式腹腔鏡マニピュレータシステムを用 い, 脾臓摘出術 2 例に適用し，(1)手術作業の妨げに ならないこと, (2)駆動範囲は充分かつ安全に手術が 遂行可能であることを確認し，これらの成果を基礎 に製品化を行なった。

\section{（2）低侵襲腹腔鏡手術支援マニピュレータシステム の開発}

京大プロジェクトで開発されているマスターアー ムと統合し，マスタースレーブマニピュレータを構 成し，肝臓低侵襲手術に代表される腹腔鏡下手術を 支援するシステムの開発を進めている．Fig. 6 にそ の機能を示す模式図を示す．マニピュレータは挿入 口を中心とする回転並進 3 自由度と鉗子軸周りの 2 自由度，鉗子先端部における屈曲 2 自由度ならびに 把持 1 自由度の合計 7 自由度を必要とする.さらに 鉗子先端部にはレーザメス，電気メスなどの機能モ ジュールを取付けた鉗子システムも開発しており. 把持・切除といった機能のみならず, 手術機器とし て必要となる機能の実現を図っている.

低侵襲腹部外科手術におけるマスタ・スレーブ型の 手術支援ロボットが種々提案されており，臨床応用 されているロボットは大型であるため，手術室への 導入困難であり，術者との干渉の危険の存在，腹部 上方の手術空間の占有などの問題点が指摘されてい る.このため小型の鉗子操作ロボットが期待されて いる．本プロジェクトでは鉗子の挿入口付近を回転 中心とする 2 自由度と, 鉗子の腹腔内一の出し入れ, 鉗子軸周りの回転の合計 4 自由度を持つ, 手術空間 を占有しない小型スレーブロボットの鉗子駆動部と して種々の方式を検討している。ここではその中か
らジンバル機構と摩擦駆動による小型鉗子駆動マニ ピュレータの開発を紹介する ${ }^{4}$. 鉗子軸に対して傾 きを持って，3 個のコロ（Roller）を接触させた機構 を摩擦車と名づける．軸に対して摩擦車が回転する とき，コロは傾きの方向に回転し，摩擦車はらせん を描く運動を行なう。らせん運動に含まれる回転成 分，および並進成分を利用して，鉗子軸の駆動を行 なら。

摩擦車の駆動には，小型・高トルクなどの点から, 超音波モータを用いる. Fig. 7-a に赤色で示す方向の モータを回転させたとき，鉗子軸には $F_{1} ， F_{2}$ の合力 $F$ が働くことにより鉗子は並進する．同様に Fig. 7-b に示すように力が働いた場合，鉗子軸は回転する。

挿入口周りの回転 2 自由度はジンバル機構を用い て実現した。駆動にはDCモータを用いる。ピッチ の回転駆動はリンク機構により伝達した。これによ り滅菌・非滅菌部の分離が可能になり, 洗浄も容易と した.

ジンバル機構の取付位置は腹壁上方 $30 \mathrm{~mm}$ とす る. 駆動範囲は, 要求仕様より腹腔内に $250 \mathrm{~mm}$ の 鉗子が挿入されているとき，ピッチ・ロールそれぞれ $40 \mathrm{deg}$ とする.

回転中心が鉗子挿入孔から腹壁上方にシフトし， 鉗子が腹壁を引張ることで，モータの負荷の増加や 挿入孔の拡大が考えられた。しかし，ブタを用いた 実験の結果，傷の拡大は確認されず，また，トルク の増加は気腹法において $2.6 \times 10^{-1} \mathrm{Nm}$, 吊上げ法に おいて $1.6 \times 10^{-1} \mathrm{Nm}$ となった。製作したマニピュ レータを示す (Fig. 8). 円筒状の回転・並進機構部は 直径 $42 \mathrm{~mm}$ ×高さ $89 \mathrm{~mm}$, 重量 $250 \mathrm{gf}$, ジンバル機 構部は $39 \mathrm{~mm} \times 54 \mathrm{~mm} \times 70 \mathrm{~mm}$, 重量 $330 \mathrm{gf}$ であ る.

\section{（3）屈曲鉗子機構の開発}

前述の鉗子駆動マニピュレータに装着し，腹腔内 に挿入し手術操作を行なう屈曲 2 自由度, 把持 1 自 由度の合計 3 自由度の屈曲鉗子を実現する方式とし て，リンク駆動方式，ワイヤ駆動方式 2 種類の方式 を検討している．リンク駆動方式は剛性が高く確実 な駆動ができるといった利点を有する。ワイヤ駆動 方式は稼動範囲の大きさ，小型化が容易といった利 点を有するが，ワイヤ切断の危険性を有しており， 本研究では用途により 2 種類の駆動方式を選択して 使用寸ることを検討している. Fig. 9 にワイヤ駆動 型の屈曲監視機構の例を示す ${ }^{56088}$.

鉗子の高機能化については Fig. 10 に示すような小 型の高出力半導体レーザを搭載したレーザマニピュ 


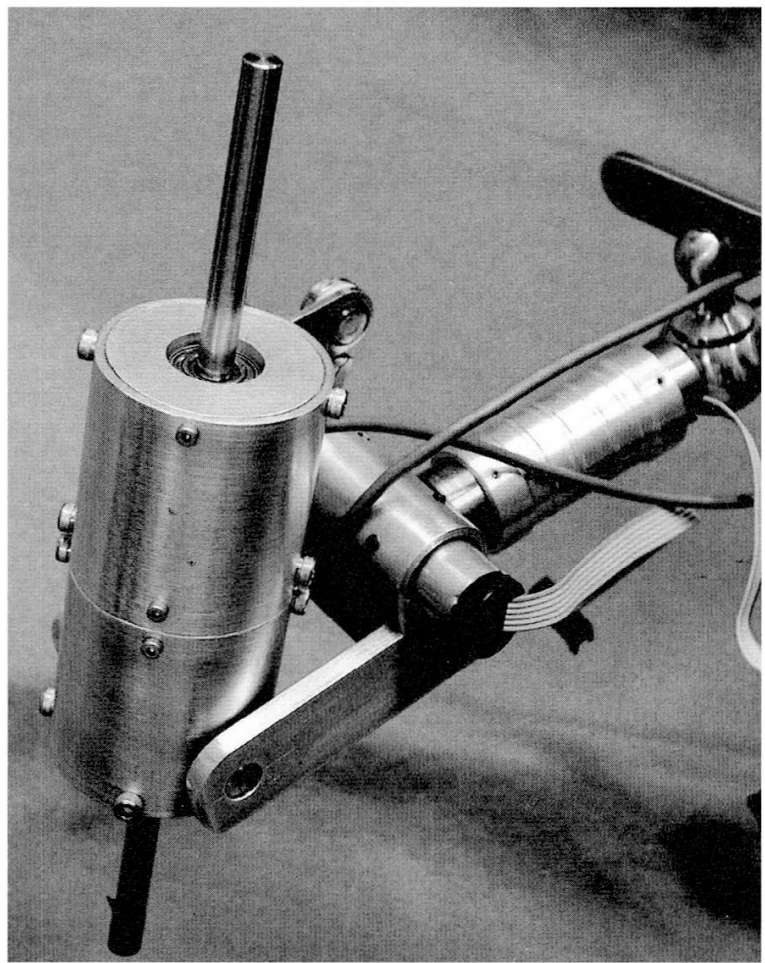

Fig. 8 Compact forceps manipulator using a friction wheel and gimbal mechanism.

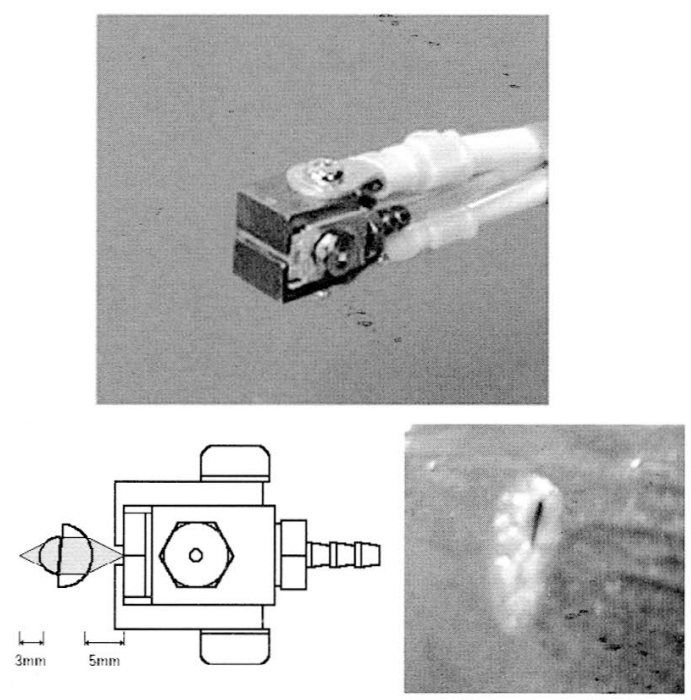

Fig. 10 Laser manipulator with high power semiconductor laser module.

レータの開発や, バイポーラ電気メ又機能の付加を 中心に研究を進めている7.

\section{（4）システム統合}

本研究ではマスタースレーブマニピュレータシス テムを阪大プロジェクト等で開発されている種々の ナビゲーションシステムや, 臓器変形解析システム

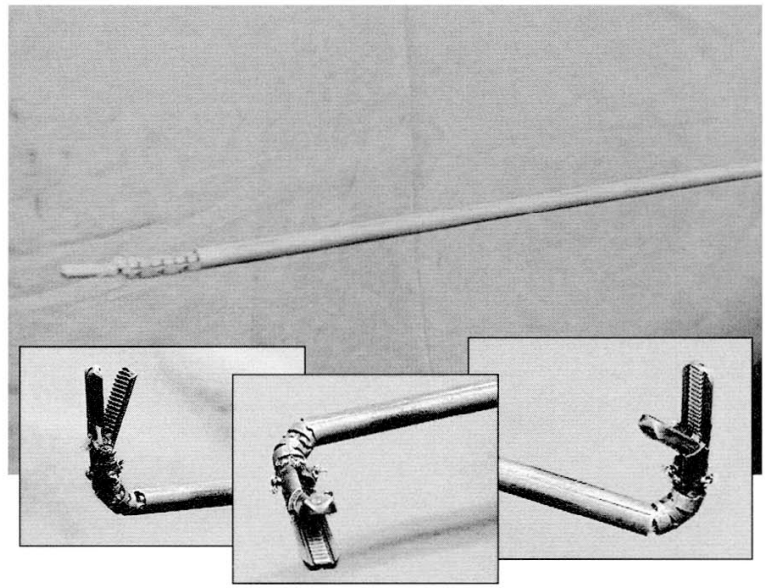

Fig. 9 Bending forceps manipulator using wire mechanism.

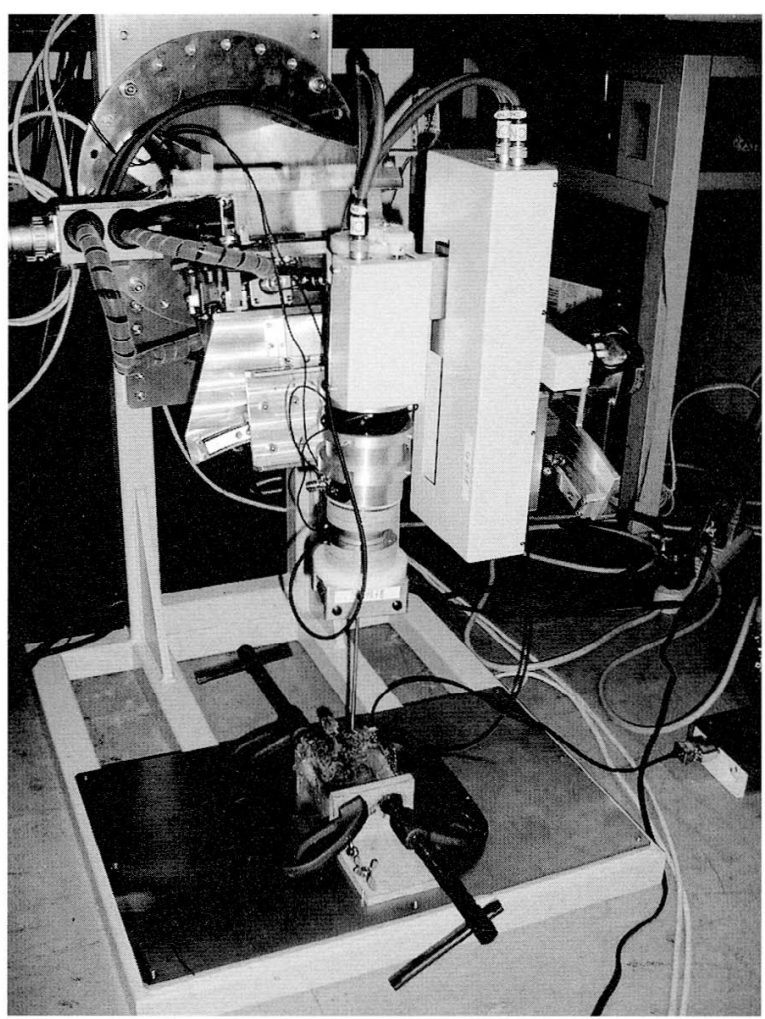

Fig. 11 Prototype of the percutenious vertebroplasty robot.

と統合して使用することを想定している。すなわち ナビゲーション技術，シミュレーション技術，ロボ ット技術などを統合したトータルシステムの完成が 望まれている。これらの個々のシステムを統合する 際，異なるハードウェアやオペレーティングシステ ム, プログラミング言語が混在しているのが現状で 


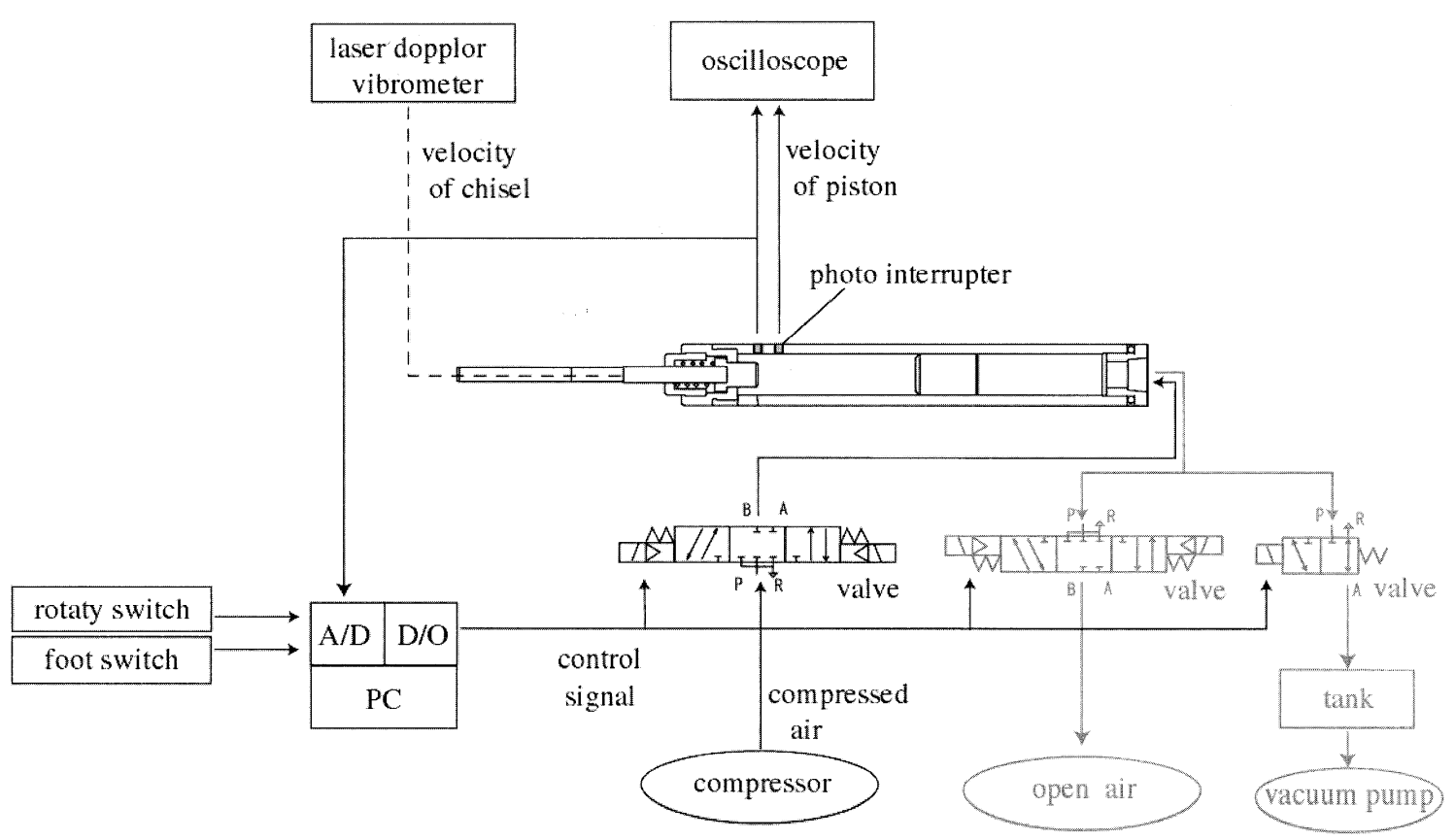

Fig. 12 System configuration of pneumatic controlled bone cutting device.

ある。本件球では分散オブジェクト技術 CORBAに よってのシステムの統合に関する研究を進めている $(\text { Fig. 11 })^{9)}$.

\section{4. 整形外科手術支援ロボットの開発}

阪大菅野プロジェクトと共同で，レーザガイダン スシステム, 椎体骨穿刺ロボットの開発を進めてい る.また骨切りを正確に行なうための骨きり機構に 関する検討も実施している.

\section{（1）骨穿刺マニピュレータの開発}

経皮的椎体形成術において椎体骨穿刺を画像誘導 型ロボットで行なうことには，三次元位置関係の把 握やX $\mathrm{X}$ 線被曝といった負担を術者に課すことなく高 精度な位置決めを実現できるという利点がある。こ のようなロボットの開発にあたり，穿刺機構を用 いて，ホルマリン固定したヒト椎体骨穿刺時の反力 （力およびトルク）を測定し，椎体骨穿刺ロボットに 要求される穿刺力を推定した.

典型的な構造の部位を適切な経路に沿って穿刺し た場合, 針送り量が約 $5 \sim 6 \mathrm{~mm}$ のとき軸力は最大 值を示したが, 全体的をして変化傾向は穿刺ごとに 大きく異なった．穿刺部位の構造および機械的強度 のバラつきが主原因と考えられる.X線 CT 画像の 輝度と軸力に相関が見られるため, 術前骨密度測定 により適切な穿刺条件設定が可能であると考えられ
る.

送り速度，回転速度の上昇はそれぞれ軸力最大值 の増加, 軸力トルクの低下につながることが確認さ れた ${ }^{10)}$.

また，ホルマリン保存ヒト大体骨頭標本を用いて， 外科医の手技による穿刺と上記ロボット機構による 穿刺時の比較を行なったさらなる検討が必要である.

\section{(2) 精密骨切機構の開発}

外科手術においては骨延長手術を始めとするいく つかの場面で，大腿骨などの骨切りが行なわれてい る. 術後の骨の成長という点から考えると骨膜と骨 髄の保護が重要である ${ }^{1)}$ が，最もオーソドックスな 骨ノミとハンマーによる骨切りにおいて必要な部分 だけの正確な切断は術者の熟練度に大きく依存して いる．骨切りの方法としては骨ノミとハンマーを用 いる方法以外に, レーザ，超音波，骨鋸を使う方法 が存在する. 切断特性はそれぞれ一長一短があるが, 術後の骨再生に重点をおくと, 熟練は要するが切断 時の熱発生の少ない骨ノミとハンマーによる切断が 優れている，課題は術者の熟練度に依らずに正確な 骨切りのできる方法を開発することである，骨ノミ を用いた骨切りにおいて，術者がハンマーによって ノミに与えていた衝撃力を空気圧制卸のピストンに 置き換えて再現性と精度の向上を図り，同時に操作 性の向上も目指したメカニズムを開発している. 


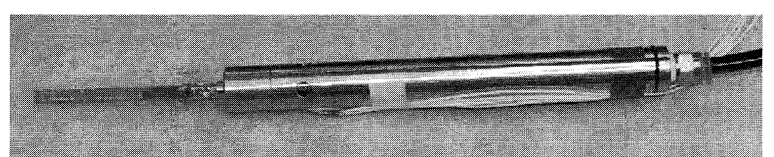

Fig. 13 Overview of the cylinder and bone chisel.

i)

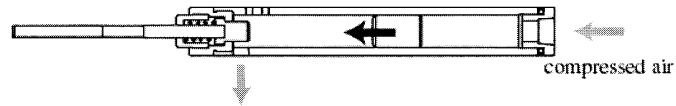

ii)

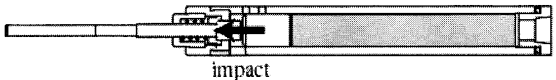

iii)

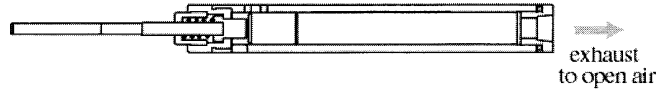

iv)

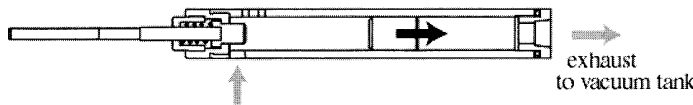

Fig. 14 Movement of the piston to initial position by negative pressure.

Fig. 12 に試作した骨切り装置の構成を示し，Fig. 13 にシリンダと骨ノミの外観を示す．前方ポートは ピストン加速時の排気とピストンを戻す時の給気に 必要であるが，シリンダ前部への給気ホースは操作 性を阻害していた。そこで真空ポンプで減圧したタ ンクを追加し，シリンダの後部にのみホースを接続 する構造とした。動作は Fig. 14 に示すように，ピス トンの衝突後に後部の圧縮空気をいったん大気中に 排気した後, 減压したタンクに接続してピストンを 吸い上げて初期位置へ戻す。ピストン駆動の最大繰 り返し速さは 70 回/分であり，対象を豚の大腿骨と した 1 回の切断量は $1 \sim 2 \mathrm{~mm}$ であった。 刃先が柔 らかい組織に当たった場合でも 1 回の切断量は $3 \mathrm{~mm}$ に抑えられており，切り過ぎの防止に役立つことが 予想される ${ }^{11}$

\section{4. まとめ}

本稿では，日本学術振興会未来開拓学術推進事業 「外科手術支援ロボティックシステム開発プロジェク 卜」の概要を解説し，そのなかからいくつかの研究 を紹介した. 平成 13 年度終了時点での成果に基づく ものである。平成 14 年度, 15 年度の研究開発によ り産業界と協力し，これら成果を基礎に実用化可能 な手術支援ロボットシステムへの展開を図ることを 予定している. 京都大学, 大阪大学, 九州大学と共 同で，肝臟低侵襲外科手術支援マスタースレーブマ
ニピュレータシステムの開発をめざし，大阪大学と 共同で整形外科手術支援用レーザガイダンスシステ ム，椎体骨穿刺支援口ボット開発を目指すこととな っている. 産学連携を推進し, 臨床現場に提供可能 な手術支援ロボットの開発を目標としている.

*

謝辞：本研究は日本学術振興会未来開拓学術推進事 業 JSPS-RFTF99I00904 による.

\section{文 献}

1) 陳献，久田俊明，佐久間一郎ほか. 非線形有限要素法 による肝臓変形シミュレーション。 JJSCAS 2002; 4: 279-280.

2) Masutani Y. Non-Rigid Registration in Image-Guided Liver Surgery based on Non-Physically based model and Physically based Model. Proc of Computer Assisted Radiology and Surgery. 2002: 754.

3) Kobayashi E, Masamune K, Sakuma I et al. A New Safe Laparoscopic Manipulator System with a Five-Bar Linkage Mechanism and an Optical Zoom. Computer Aided Surgery 1999; 4: 182-192.

4) Suzuki T, Kobayashi E, Kim D, et al. A new compact robot for manipulating forceps using friction wheel and gimbals mechanism, Computer Assisted Radiology and Surgery (CARS 2002). 2002: 314-319.

5) 渡部耕一，岡田昌史，中村仁彦。リンク駆動型高剛性 多自由度能動鉗子の開発，日本機械学会ロボティクス・ メカトロニクス講演会 2001。2001; 2P1-D10.

6) Nakamura R, Oura T, Kobayashi E, et al. Multi-DOF Manipulator System for Laparoscopic Surgery-Mechanism Miniaturized \& Evaluation of New Interface. Lecture Notes in Computer Science 2001; 2208: 606-613.

7) 秦修，小林史和，小林英津子，佐久間一郎，矢作直樹, 辻隆之，稲田紘，土肥健純．高出力半導体レーザ搭載 型手術用マニピュレータの開発。ロボティクス・メカ トロニクス講演会 2002．2002: 40.

8) Kim Y, Oura T, Kim D, et al. Study on bending forceps manipulator with electric-cautery function for aparoscopic surgery, Computer Assisted Radiology and Surgery (CARS 2002). 2002: 1089 .

9) 大杉伸也，土肥健純，波多伸彦. CORBA を用いた市 ットワーク統合システムのパフォーマンス測定および 評価. JJSCAS 2001; 3: 227-228.

10）松宮潔，桃井康行，小林英津子，菅野伸彦，米延策 雄, 稲田紘, 迲隆之, 佐久間一郎。経皮的椎体形成術 における椎体骨穿刺時反力の測定. JJSCAS 2002; 4: 265-266.

11）鈴木信，佐々木健，板生清。骨延長術手術支援入力 ニズムの開発 ; 衝撃力を利用した骨切りメカニズムの 提案, 2002 年度精密工学会春季大会学術講演会講演論 文集. 2002: 647 . 